\title{
The Disruptive Innovation Potential of Decentralized Cryptocurrencies
}

\author{
Tuna Can GÜLEÇ*
}

\begin{abstract}
The cryptocurrency market could only accomplish a small fraction of what it was capable of since Bitcoin was first popularized. Improving upon Bitcoin, the development of technically superior cryptocurrencies couldn't manage to create a disruptive innovation impact on the market either. In order to understand why the cryptocurrency market couldn't fulfill its perceived disruptive innovation potential, this study systematically reviews the literature. Relevant literature has been thoroughly searched and several studies that use certain methodologies are included in the review. These studies have been categorized based upon their approaches to the subject as supportive studies and contradictory studies. Within these categories, subsections have been created based on the findings and conclusions of each study reviewed. Following the theoretical discussion, the rationality of the movements in the market has been analyzed with regression models supported by sentimental estimation model outputs. According to the interpretation of the studies in the literature, cryptocurrencies seem to need a properly functioning natural selection mechanism, which will only allow the survival of the currencies that have the best "fit" to the needs of the market. Additionally, the findings of the regression analysis are in line with the majority of literature and suggest that the cryptocurrency prices are straight out unpredictable even with the usage of advanced AI algorithms that take human irrationality into account. Collectively, evidence suggests that in its current structural form, the ICO based cryptocurrency market is set to fail in a gradual pattern.
\end{abstract}

Key Words: Financial Markets, Fintech, Cryptocurrency

JEL Classification: G14, F30, E30

\section{Merkezi Olmayan Kriptopara Birimlerinin Yıkıcı Yenilik Potansiyeli}

\begin{abstract}
$\ddot{O} Z$
Kriptopara piyasalar, Bitcoin ilk popüler hale geldiğinden bu yana kendisinden beklenenlerin sadece küçük bir kısmını gerçekleştirebildi. Bitcoinden sonra gelen ve teknik olarak üstün niteliklere sahip kriptopara birimlerinin gelişsirilmesi, pazarda da ylkıcı bir inovasyon etkisi yaratmayı başaramadı. Kriptopara birimi piyasasının neden algılanan ylkicı yenilik potansiyelini yerine getiremediğini anlamak için, bu çalışma ilgili yazını sistematik bir şekilde incelemektedir. Yazın detaylıca incelenmiş ve belirli ölçütleri karşılayan birçok çalışma derlemeye dâhil edilmiştir. Bu çalışmalar, konuya yaklaşımlarına dayanarak, destekleyici çalışmalar ve çeliş̧ili çalışmalar olarak kategorize edilmiştir. Bu kategorilerde, incelenen her çalışmanın bulgularına ve sonuçlarına dayanarak alt bölümler oluşturulmuştur. Teorik tartışma sonrasında, sezgisel yapay zeka algoritma çıktılarıyla desteklenen bir regresyon modeli kullanılarak piyasadaki fiyat hareketlerinin rasyonelliği test edilmiştir.Yazındaki çalışmalardan yola çıkarak varılan sonuca göre, kriptopara birimleri, sadece piyasa ihtiyaçlarına en uygun niteliklere sahip olan para birimlerinin hayatta kalmasina izin verecek şekilde çalışan bir doğal seçilim mekanizmasına ihtiyaç duymaktadır. Ek olarak, regresyon analizinin bulguları yazın ile eş yönlüdür ve kripto para birimi fiyatlarının, insan irrasyonelliğini hesaba katan gelişmiş AI algoritmalarının kullanımıyla bile doğrudan tahmin edilemez olduğunu
\end{abstract}

\footnotetext{
*Araş. Gör. Dr. Manisa Celal Bayar Üniversitesi Uygulamalı Bilimler Fakültesi, Bankacılık ve Finans Bölümü. tunacan.gulec@cbu.edu.tr, ORCID bilgisi: 0000-0003-2551-6460
} 
göstermektedir. Tüm bunlar bir bütün olarak, mevcut ICO tabanlı kriptopara piyasasının kademeli bir şekilde başarısız olacă̆ına işaret etmektedir.

Anahtar Kelimeler: Finansal Piyasalar, Fintek, Kriptopara

JEL Sinıflandirmasi: G14, F30, E30

\section{INTRODUCTION}

In popular culture, the concept of digital currency usually refers to the cryptocurrency market that is believed to be a speculative bubble in which irrational speculators and manipulators gamble. While this is true for the majority of altcoins, the term of "digital currency" originally refers to a promise of a decentralized world currency that every human can use anonymously without having citizenship or being a member of a company. The ideal digital currency is thought to be completely decentralized, perfectly efficient, immune to manipulations, a stable store of value, and most importantly "the" medium of exchange. Digital currency is not the same thing as a cryptocurrency, there are several algorithms that do not use cryptographic hash functions to operate. Similarly, mining is not an integral part of digital currencies.

In order for a digital currency to be considered as "decentralized", it should be impossible for any group or identity such as governments, companies or investment funds to control the system in any way other than being a participant in it. In a peer-to-peer system design, there are no main servers in which authorities can shut down. Similarly, no private company is able to take control of the system over. The main reason why a decentralized system is sought after in digital currencies, however, is not the desire of user anonymity. The main benefit of using a decentralized system is being exempt from the "inflation tax" which is an intrinsic component of any monetary policy. This exemption allows decentralized digital currencies to maintain their original value without requiring any investment. On the other hand, on a decentralized currency changing the original code is not possible. This can be considered as the main shortcoming of a decentralized system.

Market efficiency is a critical factor for any financial asset or currency. In order for the transfer and storage of value to commence, prices must reflect the perceived value for any good or service at any given time. Any sustained diversion between these two results in speculative bubbles consequently followed by market crashes. As of March 2019, there are more than 2100 listed coins under the cryptocurrencies category. Most of these currencies have either the same structure or have only minor changes that won't affect the system. A handful of these digital currencies can be considered as an upgrade or evolution from Bitcoin, however, their market volumes are too shallow to be able to operate efficiently. This situation causes the majority of the market to get stuck in the low-tech coins such as Bitcoin or Litecoin.

First-generation coins such as Bitcoin and Litecoin lack the abilities required to become a worldwide currency. The first problem is the transaction times. For a system that aims to replace the whole financial system, these coins are extremely slow. A meager transaction takes longer than a day to take place. This clumsiness makes these currencies impossible to use practically. Transaction cost 
is another substantial problem. The transaction cost for any transaction is increasing each day with an increase in mining costs. There are several methods that take place of "Proof of Work" concept that does not waste the resources of humanity. The baseline is, cryptocurrencies as of their first-generation forms are set to fail if they remain as they are since 2009 .

The reason why these markets are unable to evolve is popularly discussed by market participants and Fintech enthusiasts. While it is hard to know for certain, one of the elements contributing to this is the emotional attachment factor. Bitcoin's name is so widely known that it is used almost synonymously with the term "Cryptocurrency". A group of investors who have not only financially and emotionally invested in their selected currencies but also refuse to sell their supported currency regardless of market prices and volatility. This group is named "hodl". Another factor is the financial illiteracy of investors within the market.

Another significant factor that contributes to the market volatility is initial coin offerings conducted every day. Regardless of their technological structure, initially offered coins have unacceptable risk levels associated with them. Initiators of these ICO's are a risk factor by themselves. Usually, the initiator group takes over a certain amount of predetermined currency as their payment for creating the coin. While the coin itself may still technically considered decentralized, the accumulation of wealth in these markets indicates significant risks for new investors. This inherent risk structure in newly offered coins makes them unfit to be invested by the majority of investors. Accordingly, with this low number of investors, markets stay shallow, and low market depth in an already unregulated market becomes infinitely risky for anyone but their initial offerees. While investors may have experience in conventional financial instruments, digital currencies have different market dynamics and for most of the investors, the technological and financial implications of initial coin offerings are not understood well enough to decide efficiently. This high level of information requirement limits the market efficiency. Under these circumstances, the future of cryptocurrency markets is essentially dependent upon becoming an efficient market without bubbles or manipulations to be able to function properly, even then however it might not be enough to become an actual currency due to lack of common trust in the currency.

In the analysis part of the study, we test for the explaining power of sentimental inputs in the equilibrium process of cryptocurrency market prices. Using publicly available third party sentimental analysis outputs(discussed at length in the discussion section), we test for the explanatory power of human sentiment on Bitcoin prices. The assumption underlying the second part of the study is that, in order for the cryptocurrency market to fulfill its potential, the market movements should be explainable by sentimental human actions and not just by profit-oriented trading.

\section{LITERATURE}

Literature is reviewed by collecting significant studies on the subject and allocating them under two primary categories. The first category contains studies 
that accept the legitimacy of cryptocurrencies in general and accept them as a replacement alternative or as potential components of the financial system. This category is called supportive studies and divided into 3 subcategories. The first subcategory is the Alternative Replacement category and symbolizes studies that view cryptocurrencies as a disruptive innovation that will possibly replace the current financial system. The second subcategory is named Potential Components and these studies imply the coexistence of cryptocurrencies along with the existing financial system. Conflicting Results subcategory represents studies that find evidence conflicting with the view of supporting studies while maintaining a supportive stance.

Table 1. List of Supportive Studies

\begin{tabular}{|c|c|c|c|c|}
\hline Author (date) & Focused Coins & $\begin{array}{c}\text { Alternative } \\
\text { Replacement }\end{array}$ & $\begin{array}{c}\text { Conflicting } \\
\text { Results }\end{array}$ & $\begin{array}{c}\text { Potential } \\
\text { Component }\end{array}$ \\
\hline (Cocco et al., 2017) & Artificially Simulated Coin & + & & \\
\hline (Scott, 2016) & Blockchain 2.0 System & + & & \\
\hline (Chen et al., 2017) & $\begin{array}{c}\text { Portfolio of Coins } \\
\text { Bitcoin Ethereum Dash }\end{array}$ & + & & \\
\hline (Sovbetov, 2018) & Monero & + & & \\
\hline (Alam, 2017) & Bitcoin & + & & \\
\hline (Burnie et al., 2018) & Altcoins & + & & \\
\hline (Farell, 2015) & Bitcoin & + & & \\
\hline (Fry \& Cheah, 2016) & Bitcoin, Ripple & + & & \\
\hline (Foy, 2019) & Classification of BTC & + & & \\
\hline (Hayes, 2017) & $\begin{array}{c}\text { Cost-based Valuation } \\
\text { Model }\end{array}$ & + & & \\
\hline (Chuen et al., 2017) & CRIX Index & + & & \\
\hline (Cheung et al., 2015) & MtGox Portfolio & + & & \\
\hline (Bian et al., 2018) & ICO Rating System & + & & \\
\hline (Liu \& Tsyvinski, 2018) & Bitcoin, Ripple, Ethereum & + & & \\
\hline (Caporale et al., 2018) & BTC,LTC,XRP, Dash & + & & \\
\hline (Catania et al., 2018) & BTC, ETH, LTC, XRP & + & & \\
\hline (Halaburda \& Gandal, 2016) & Bitcoin & + & & \\
\hline (Güleç \& Aktaş, 2019) & 8 Cryptocurrencies & + & & \\
\hline (Howell et al., 2018) & Filecoin & & - & \\
\hline (Brenig et al., 2015) & Bitcoin & & - & \\
\hline (Brown, 2016) & Cybercrime Aspect & & - & \\
\hline (Eyal, 2017) & Bitcoin & & - & \\
\hline (Iwamura et al., 2014) & Bitcoin & & & + \\
\hline (Ametrano, 2016) & Monetary Model of Hayek & & & + \\
\hline (Singh \& Davidson, 2018) & Cryptocurrency Market & & & + \\
\hline (Raymaekers, 2015) & Bitcoin & & & + \\
\hline (Wörner et al., 2016) & Bitcoin & & & + \\
\hline (Taskinsoy, 2018) & Bitcoin & & & + \\
\hline (Makarov \& Schoar, 2018) & Bitcoin Arbitrage & & & + \\
\hline
\end{tabular}


The second category of studies is the studies that are contradictory to the view that cryptocurrencies have the potential to be a legitimate component of the financial system due to various reasons. These studies are categorized accordingly with the main argument they use in the opposition of cryptocurrencies. Studies that argue in the financial or the economic aspect of the system are categorized under the Market Efficiency base of rejection, while studies that are against the technical elements that are used in the cryptocurrencies are categorized under Technological Infrastructure subcategory. Additionally, the Moral Hazard category focuses on the vulnerability of the system to moral exploitations.

Table 2. The List of Contradictory Studies

\begin{tabular}{|c|c|c|}
\hline Author (date) & Focus & The Base of the Rejection \\
\hline (Zetzsche et al., 2017) & Price Bubbles, ICOs & Market Efficiency \\
\hline (Hamrick et al., 2018) & Pump \& Dump Manipulations & Market Efficiency \\
\hline (Umeh, 2016) & Price Bubbles & Market Efficiency \\
\hline (Mensi et al., 2019) & Inefficient Pricing Dynamics & Market Efficiency \\
\hline (Kamps \& Kleinberg, 2018) & Pump \& Dump Manipulations & Market Efficiency \\
\hline (Bouoiyour et al., 2014) & Price Bubbles and Manipulations & Market Efficiency \\
\hline (Barnes, 2018) & Manipulations and Bubbles & Market Efficiency \\
\hline (Baum, 2018) & Pump \& Dump Manipulations & Market Efficiency \\
\hline (Constantinescu, 2018) & National Security Concerns & Technological Infrastructure \\
\hline (Evans-Pughe et al., 2014) & Crypto Exchange Problems & Technological Infrastructure \\
\hline (Bratspies, 2018) & Trustless Transaction & Technological Infrastructure \\
\hline (Torres \& Steichen, 2019) & Smart Contract Issues & Technological Infrastructure \\
\hline (Engle, 2015) & Security Concerns & Moral Hazard \\
\hline (Majumder et al., 2019) & Terror Financing & Moral Hazard \\
\hline (Capital, 2016b) & Cybercrime & Moral Hazard \\
\hline (Capital, 2016a) & Cybercrime & Moral Hazard \\
\hline (Reddy \& Minnaar, 2018) & Cybercrime & Moral Hazard \\
\hline (Jacquez, 2016) & Money Laundering & Moral Hazard \\
\hline (Stokel-Walker, 2018) & Hacks and Scams & Moral Hazard \\
\hline
\end{tabular}

\section{ANALYSIS}

A regression analysis has been conducted using the logarithmic return series of BTC and the market sentiment analysis values available publicly through API interface by alternative.me (Crypto Fear \& Greed Index - Bitcoin Sentiment, 2019). Dataset consists of 700 daily observations until January 1, 2020. While it is only a univariate regression analysis that is conducted in the study, the algorithm that leads to the creation of investor sentiment values is calculated through a complex process that involves the use of various AI models, and financial 
transaction analysis bots. While keeping the source code private, the information source expresses the algorithm with the following model:

Sentiment $=0.25$ Volatility +0.25 Market Momentum

$$
\begin{aligned}
& +0.15 \text { Social Media Sentiment } \\
& +0.10 \text { Market Concentraiton }+0.10 \text { Google Trends } \\
& +0.15 \text { Investor Surveys }
\end{aligned}
$$

The resulting Sentiment value from the model is a value that fluctuates between 1 to 100, recalculated each day. This value is regressed using daily BTC

\begin{tabular}{|c|c|c|c|c|}
\hline Variable & Coefficient & Std. Error & t-Statistic & Prob. \\
\hline LOG(Sentiment) & 0.214421 & 0.046419 & 4.619227 & 0.0000 \\
\hline $\mathrm{C}$ & 8.125657 & 0.163318 & 49.75352 & 0.0000 \\
\hline R-squared & 0.110685 & \multicolumn{2}{|l|}{ Mean dependent var } & 8.884950 \\
\hline Adjusted R-squared & 0.109709 & \multicolumn{2}{|l|}{ S.D. dependent var } & 0.326183 \\
\hline S.E. of regression & 0.307770 & \multicolumn{2}{|l|}{ Akaike info criterion } & 0.483260 \\
\hline Sum squared resid & 86.38699 & \multicolumn{2}{|l|}{ Schwarz criterion } & 0.493802 \\
\hline Log-likelihood & -218.8498 & \multicolumn{2}{|l|}{ Hannan-Quinn criteria. } & 0.487284 \\
\hline F-statistic & 113.5079 & \multicolumn{2}{|l|}{ Durbin-Watson stat } & 0.040248 \\
\hline Prob(F-statistic) & 0.000000 & \multicolumn{2}{|l|}{ Wald F-statistic } & 21.33726 \\
\hline \multirow[t]{2}{*}{ Prob(Wald F-statistic) } & 0.000004 & & & \\
\hline & \multicolumn{4}{|c|}{ Heteroskedasticity Test: Breusch-Pagan-Godfrey } \\
\hline \multirow[t]{2}{*}{ F Statistic } & 2.6905 & \multicolumn{2}{|c|}{ Prob $F(1,912)$} & 0.1013 \\
\hline & \multicolumn{4}{|c|}{ Breusch-Godfrey Serial Correlation LM Test: } \\
\hline F Statistic & 13,426 & \multicolumn{2}{|l|}{ Prob F(2,910) } & 0.0000 \\
\hline
\end{tabular}
return series. The results of the analysis are reported in Table 3.

Table 3. Results of the Human Sentiment Predictions Regression

The model is estimated using the Newey-West moment estimation method due to the implied auto-correlation problem. Results indicate that a $10 \%$ change in Sentiment value is likely to result in a $2.1 \%$ change in the BTC prices. Furthermore, $\mathrm{R}$-squared value implies that the sentimental analysis values can only explain $11 \%$ of the changes in BTC prices.

\section{DISCUSSION}

Studies that are supportive of the cryptocurrencies, are by large consider the cryptocurrencies and its blockchain-based components as a replacement to the current financial system. The most significant common ground in supportive studies is that almost all of them foresee a transition from older cryptocurrencies to new generation ones. Therefore, it is safe to claim that the overwhelming majority of the literature agrees that the first generation of cryptocurrencies such as Bitcoin and Litecoin cannot be the ultimate solution in the market. For example, Cocco et. al. (2017) have used an artificially simulated coin to test for human behavior in the virtual cryptocurrency markets. They have found supporting evidence that newly issued coins may eventually dominate the market. While there are some "Bitcoin Supremacists" studies in the literature that defend that the current Bitcoin currency is good enough the way it is(Farell, 2015), the majority supportive studies do not just ignore the problems that are obvious in the cryptocurrency markets. Outdated 
blockchain algorithms such as the one used in the Bitcoin creates excessive transaction times while wasting tremendous amounts of energy in the form of electricity. Some studies counter these arguments by claiming that the current financial system is using far more energy than what Bitcoin would be using instead(Alam, 2017). The transaction times argument is countered by offering the usage of external networks such as the lightning network. However, in practice, their usage may create weaknesses in the security of the system. Supportive studies defend that the current problems in the system are due to the outdated blockchain infrastructure of mining based cryptocurrencies (Halaburda \& Gandal, 2016). Some studies offer blockchain systems that are far more advanced than the first version of blockchain infrastructure while sacrificing nothing in terms of security. In his paper, Scott (2016) has designed infrastructure for a solidarity finance system in which there is no profit-seeking third party or intermediary. Similar improvements upon blockchain infrastructure are being continuously developed by independent parties. Cryptocurrencies that are able to operate without a mining component are recently being introduced into the system. Having one of the most controversial components of the blockchain removed from the system is thought to be a substantial improvement upon existing systems. On the other hand, the security of these cryptocurrencies is currently still under question. Cryptocurrencies such as Cardano, NEO, IOS, or IOTA are currently widely in use without any major security weaknesses in their infrastructure. While a good number of studies support the viability of these coins(Cheung et al., 2015; Chen et al., 2017; Güleç \& Aktaş, 2019), there are a number of complications in the usage of these currencies as well. The most popular alternative to mining is made by replacing the Proof of Work system by Proof of Stake system. While having resulting is much less energy usage, proof of stake system also empowers users of the currency based upon their shares. In other words, richer you are, bigger say you have in the future of the currency. This aspect contradicts with the decentralized structure of cryptocurrencies.

Studies in the supportive category rationalize the existence of cryptocurrencies in economic and financial terms as well. Since the first time they come into existence, the cryptocurrencies have been in a significant rise trend. The financial problem, however, is not that they are unprofitable but that they are extremely volatile. This renders them incapable of having the economic properties of money. A number of studies have studied this matter and pointed out that a currency with such a high amount of volatility levels cannot be reliably used as a store of value(Ametrano, 2016; Eyal, 2017; Taskinsoy, 2018). Another economic aspect of the problem is the fixed amount of supply. A fixed or foreseeably steady amount of money supply causes the currency to gain value over time passively. This creates a negative propensity to spend for the holders of these currencies. While this may not seem to be a problem at first, at macro levels it may create worldwide stagflation when the currency is adopted internationally. In addition to these implications currently, the cryptocurrency market is not regulated by any entity. While regulations can be forced upon cryptocurrency exchanges located in developed countries, an exchange in for example the Cayman Islands may not be 
regulated. This situation creates a perfect environment for market manipulation. A number of supportive studies have focused on this aspect of the market, according to these studies (Brenig et al., 2015; Brown, 2016; Howell et al., 2018; Iwamura et al., 2014; Singh \& Davidson, 2018), the most prevalent type of manipulation of cryptocurrency markets are the Pump \& Dump manipulations. Newly introduced coins are offered into the market via the process called ICO (Initial Coin Offering). And almost all of them are considered scams by even supportive studies.

To sum up the views of the supportive studies, a vast majority of them are supporting an evolved version of the original blockchain infrastructure and Bitcoin. The mining component of cryptocurrencies such as Proof of Work is seen mostly as a temporary solution until a better algorithm with no energy waste mechanism arrives. The volatility of the market is seen as it is going to vanish once the market is deep enough so that no manipulator can intervene. Almost all altcoins are recognized as scams or faulty to be switched as of now. And lastly, market regulations are being generally seen as they can be handled by an internal algorithm within the ideal blockchain infrastructure. Lastly, the literature is equally divided into the privacy concept. While some studies defend that the ideal cryptocurrency should be anonymous, others rightly claim that it would create a hole for illegal activities.

Studies that contradict the idea of cryptocurrencies or blockchain mainly focus on the efficiency of the market. Currently, there is an excessive amount of speculative price bubbles in the market and these studies are unconvinced that they are preventable by any means. The study of Zetzsche et.al. (2017) for example claims that the whole ICO market can be defined as a Gold Rush and investors who participate in these markets are taking irrational risks. A substantial amount of studies support this view and accept this as one of the most significant indicators that cryptocurrencies are not a legitimate financial system alternative(Barnes, 2018; Bouoiyour et al., 2014; Umeh, 2016).

The technological infrastructure of the cryptocurrencies is also a widely discussed topic of criticism. A study by Torres and Steichen (2019) claims that there are bugs in the Ethereum based smart contracts and that it is a critical security concern for the whole system. Similarly, Bratspies (2018) contradicts the idea of trustless transaction in the blockchain-based cryptocurrencies. The availability of the whole transaction records to anyone in the network is also seen as a national security issue by some studies(Constantinescu, 2018).

An objection that almost every study in the literature agrees on is the vulnerability of crypto exchanges to hacker attacks or moral hazards. While the blockchain system may be impregnable, crypto exchanges are not and there are a lot of examples to support this. The study of Evans et.al. (2014) discusses how the individual user is prone to these attacks even though there may be no vulnerability to the blockchain system.

Moral hazard is one of the most discussed issues regarding the cryptocurrencies, this category includes the issues regarding the use of cryptocurrency is deep web marketplaces, terrorism financing or in money 
laundering(Capital, 2016a, 2016b; Reddy \& Minnaar, 2018). This topic has no absolute solution so far and it's a decision between keeping the system transparent or anonymous. Keeping the system anonymous has implications regarding the prevention of cybercrimes while keeping the system transparent violates personal privacy and can cause national security issues(Jacquez, 2016; Majumder et al., 2019; Stokel-Walker, 2018). There are middle methods that can be used only to reveal the transaction information of suspected individuals however, so far no working example has been developed.

Overall the concerns of the contradictory studies are mainly focused on the financial and security aspects of the cryptocurrencies. Solutions to these issues are still being developed in the literature every passing day. However, solving moral issues may not be as straightforward as solving technical or financial problems.

\section{CONCLUSION}

The expectations regarding the future of decentralized cryptocurrencies differ greatly by the person yet, there is an almost common consensus on the fact that currently, neither people nor the market is ready for this transformation. Financial instruments and institutions have kept developing themselves for decades due to the fact that they are driven by the pursuit of wealth maximization. In a decentralized system, there are no stakeholders that can dominate the system, while this can be good for preserving the rights of everyone equally, seeking the approval of a majority in every decision also slows down the development process. As there will always be groups of people with opposing views, the separations of stakeholders in such systems are unavoidable. Hence we have over 2000 cryptocurrencies today. Cybercrime and cyber terrorism are aspects of the cryptocurrency market that are misleadingly overestimated and will probably be prevented by the time this technology is adaptable to daily usage.

A substantial portion of supportive studies is focused on the current success of these cryptocurrencies in terms of their return to investors. However, these currencies are not made for price speculation, they are crated with the idea of usage on a daily basis. The price of Bitcoin or any other currency does not positively affect the cryptocurrency market as long as it doesn't translate into adaptation or usage. The success for cryptocurrencies should be measured by the number of merchants that are willing to sell their goods in exchange for cryptocurrencies, or by the number of users that accept their payments in these terms. And currently, the overwhelming number altcoins prevent the market from being adapted by users by creating extreme volatility. Test results of our study also support this view by pointing out that the movements in the market are completely unpredictable by advanced AI software or algorithms. Which may imply that movements are completely random or manipulatory.

It is clear that the market cannot thrive as long as a mechanism to prevent this chaotic behavior is implemented. Further studies should be made regarding ways of unifying the market participants and taking necessary precautions against further manipulatory actions. 


\section{REFERENCES}

Alam, S. (2017). Testing the weak form of an efficient market in cryptocurrency. Journal of Engineering and Applied Sciences, 12(9), 2285-2288.

Ametrano, F. M. (2016). Hayek money: The cryptocurrency price stability solution. Available at SSRN 2425270.

Barnes, P. (2018). CryptoCurrency and its Susceptibility to Speculative Bubbles, Manipulation, Scams, and Fraud. Journal of Advanced Studies in Finance (JASF), 9(2 (18)), 60-77.

Baum, S. C. (2018). Cryptocurrency Fraud: A Look Into The Frontier of Fraud.

Bian, S., Deng, Z., Li, F., Monroe, W., Shi, P., Sun, Z., Wu, W., Wang, S., Wang, W. Y., \& Yuan, A. (2018). Icorating: A deep-learning system for scam ico identification. ArXiv Preprint ArXiv:1803.03670.

Bouoiyour, J., Selmi, R., \& Tiwari, A. (2014). Is Bitcoin business income or speculative bubble? Unconditional vs. Conditional frequency domain analysis.

Bratspies, R. M. (2018). Cryptocurrency and the Myth of the Trustless Transaction.

Brenig, C., Accorsi, R., \& Müller, G. (2015). Economic Analysis of Cryptocurrency Backed Money Laundering. ECIS.

Brown, S. D. (2016). Cryptocurrency and criminality: The Bitcoin opportunity. The Police Journal, 89(4), 327-339.

Burnie, A., Burnie, J., \& Henderson, A. (2018). Developing a Cryptocurrency Assessment Framework: Function over Form. Ledger, 3.

Capital, G. (2016a). Cryptojacking: A new method for criminals to stole cryptocurrency.

Capital, G. (2016b). In Cryptocurrency, Good projects can turn into scams.

Caporale, G. M., Gil-Alana, L., \& Plastun, A. (2018). Persistence in the cryptocurrency market. Research in International Business and Finance, 46, 141-148.

Catania, L., Grassi, S., \& Ravazzolo, F. (2018). Predicting the volatility of cryptocurrency time-series. In Mathematical and Statistical Methods for Actuarial Sciences and Finance (pp. 203-207). Springer.

Chen, S., Chen, C. Y.-H., Härdle, W. K., Lee, T., \& Ong, B. (2017). Econometric Analysis of a Cryptocurrency Index for Portfolio Investment. In Handbook of Blockchain, Digital Finance, and Inclusion, Volume 1 (pp. 175-206). Elsevier.

Cheung, A., Roca, E., \& Su, J.-J. (2015). Crypto-currency bubbles: An application of the PhillipsShi-Yu (2013) methodology on Mt. Gox bitcoin prices. Applied Economics, 47(23), 23482358.

Chuen, K., Lee, D., Guo, L., \& Wang, Y. (2017). Cryptocurrency: A new investment opportunity?

Cocco, L., Concas, G., \& Marchesi, M. (2017). Using an artificial financial market for studying a cryptocurrency market. Journal of Economic Interaction and Coordination, 12(2), 345365.

Constantinescu, M. (2018). CRYPTOCURRENCIES-NATIONAL SECURITY IMPLICATIONS. Defense Resources Management in the 21st Century, 13(13), 115-119.

Crypto Fear \& Greed Index-Bitcoin Sentiment. (n.d.). Retrieved August 8, 2020, from https://alternative.me/crypto/fear-and-greed-index/

Engle, E. (2015). Is bitcoin rat poison: Cryptocurrency, crime, and counterfeiting (CCC). J. High Tech. L., 16, 340.

Evans-Pughe, C., Novikov, A., \& Vitaliev, V. (2014). To bit or not to bit?[Bitcoin cryptocurrency]. Engineering \& Technology, 9(4), 82-85.

Eyal, I. (2017). Blockchain technology: Transforming libertarian cryptocurrency dreams to finance and banking realities. Computer, 50(9), 38-49.

Farell, R. (2015). An analysis of the cryptocurrency industry.

Foy, J. (2019). Financial Accounting Classification of Cryptocurrency.

Fry, J., \& Cheah, E.-T. (2016). Negative bubbles and shocks in cryptocurrency markets. International Review of Financial Analysis, 47, 343-352.

Güleç, T. C., \& Aktaş, H. (2019). Kriptopara Birimleri Piyasasında Pump\&Dump Manipulasyonlarının İki Aşamalı Analizi. Atatürk Üniversitesi İktisadi ve İdari Bilimler Dergisi, 33(3), 919-932. 
Halaburda, H., \& Gandal, N. (2016). Competition in the cryptocurrency market. Available at SSRN 2506463.

Hamrick, J., Rouhi, F., Mukherjee, A., Feder, A., Gandal, N., Moore, T., \& Vasek, M. (2018). The Economics of Cryptocurrency Pump and Dump Schemes.

Hayes, A. S. (2017). Cryptocurrency value formation: An empirical study leading to a cost of production model for valuing bitcoin. Telematics and Informatics, 34(7), 1308-1321.

Howell, S. T., Niessner, M., \& Yermack, D. (2018). Initial coin offerings: Financing growth with cryptocurrency token sales. National Bureau of Economic Research.

Iwamura, M., Kitamura, Y., Matsumoto, T., \& Saito, K. (2014). Can we stabilize the price of a Cryptocurrency?: Understanding the design of Bitcoin and its potential to compete with Central Bank money. Understanding the Design of Bitcoin and Its Potential to Compete with Central Bank Money (October 25, 2014).

Jacquez, T. (2016). Cryptocurrency the new money laundering problem for banking, law enforcement, and the legal system.

Kamps, J., \& Kleinberg, B. (2018). To the moon: Defining and detecting cryptocurrency pump-anddumps. Crime Science, 7(1), 18.

Liu, Y., \& Tsyvinski, A. (2018). Risks and Returns of Cryptocurrency. National Bureau of Economic Research.

Majumder, A., Routh, M., \& Singha, D. (2019). A Conceptual Study on the Emergence of Cryptocurrency Economy and Its Nexus with Terrorism Financing. In The Impact of Global Terrorism on Economic and Political Development: Afro-Asian Perspectives (pp. 125138). Emerald Publishing Limited.

Makarov, I., \& Schoar, A. (2018). Trading and arbitrage in cryptocurrency markets.

Mensi, W., Al-Yahyaee, K. H., \& Kang, S. H. (2019). Structural breaks and double long memory of cryptocurrency prices: A comparative analysis from Bitcoin and Ethereum. Finance Research Letters, 29, 222-230.

Raymaekers, W. (2015). Cryptocurrency Bitcoin: Disruption, challenges and opportunities. Journal of Payments Strategy \& Systems, 9(1), 30-46.

Reddy, E., \& Minnaar, A. (2018). Cryptocurrency: A tool and target for cybercrime. Acta Criminologica: Southern African Journal of Criminology, 31(3), 71-92.

Scott, B. (2016). How can cryptocurrency and blockchain technology Play a role in building social and solidarity finance? UNRISD Working Paper.

Singh, D. J., \& Davidson, J. (2018). Bitcoins and Cryptocurrency-Scam, Bubble or Currency of the Future? (Vol. 5). Mendon Cottage Books.

Sovbetov, Y. (2018). Factors influencing cryptocurrency prices: Evidence from bitcoin, ethereum, dash, litcoin, and monero. Journal of Economics and Financial Analysis, 2(2), 1-27.

Stokel-Walker, C. (2018). The murky world of the bitcoin scam. New Scientist, 3160, 12.

Taskinsoy, J. (2018). Bitcoin Mania: An End to the US Dollar's Hegemony or another Cryptocurrency Experiment Destined to Fail? Available at SSRN 3311989.

Torres, C. F., \& Steichen, M. (2019). The Art of The Scam: Demystifying Honeypots in Ethereum Smart Contracts. ArXiv Preprint ArXiv:1902.06976.

Umeh, J. (2016). Blockchain double bubble or double trouble? Itnow, 58(1), 58-61.

Wörner, D., Von Bomhard, T., Schreier, Y.-P., \& Bilgeri, D. (2016). The Bitcoin ecosystem: Disruption beyond financial services?

Zetzsche, D. A., Buckley, R. P., Arner, D. W., \& Föhr, L. (2017). The ICO Gold Rush: It's a scam, it's a bubble, it's a super challenge for regulators. University of Luxembourg Law Working Paper, 11, 17-83. 